\title{
Some Eocene Cerithioids (Gastropoda, Mollusca) from Kutch, Western India, and Their Bearing on Palaeobiogeography of the Indian Subcontinent
}

\author{
Kalyan Halder and Piyali Sinha \\ Department of Geology, Presidency University, 86/1 College Street, Kolkata 700073, India \\ Correspondence should be addressed to Kalyan Halder; kalyan.geol@presiuniv.ac.in
}

Received 30 April 2014; Accepted 5 July 2014; Published 6 August 2014

Academic Editor: Dany Azar

Copyright (c) 2014 K. Halder and P. Sinha. This is an open access article distributed under the Creative Commons Attribution License, which permits unrestricted use, distribution, and reproduction in any medium, provided the original work is properly cited.

\begin{abstract}
The cerithioids are a diverse group of gastropods found globally as fossil and living animals during the Cenozoic Era. Their systematics is riddled with problems stemming from large morphological variability, homoplasy, and wide geographical distribution. Six cerithioid species are described here from the lower Middle Eocene of Kutch, Gujarat, western India. All but two are new species. They are Palmerella kutchensis, Tenagodus? sowerbyi, Potamides archiaci, and Cerithium harudiensis. The rest are new records from Kutch and were known only from Pakistan. A palaeobiogeographical review based on major published records of benthic molluscs from Pakistan reveals strong endemism. The cerithioid faunas from different parts of Pakistan and this report from Kutch also show strong endemism and often quite localized development. It is argued here that unhindered faunal mixing was not possible in this province since these newly evolved basins were restricted in nature in their Lower Cenozoic history.
\end{abstract}

\section{Introduction}

Cerithioids are an extremely diverse and less understood group of gastropods. It includes the family Turritellidae with one of the highest specific diversity among gastropods since the Late Cretaceous period. Their taxonomic prodigality does not reflect on morphological disparity. The simple turreted coiling characterizes all cerithioids. Cerithioid species are often defined based on very small and minute differences in characters. Again, many species, especially geographically widespread ones, have extremely variable morphological features resulting in large overlapping in several attributes with one or another species (e.g., see Houbrick [1] and Reid et al. [2]). Morphological convergence is also common in higher taxonomic categories, such as families and genera [3].

The superfamily Cerithioidea has been variously interpreted in recent times. In an effort to make sense of this poorly understood group different researchers have placed varied importance to different sets of characters, often without a critical appreciation of their evolutionary significances. The superfamily does not include the family Turritellidae in Bandel's [3] classification scheme based primarily on protoconch characters. Protoconch characters, generally appearing to remain fairly constant in genera and families, have been given high weightage. However, classification schemes based on other presumably stable characters, such as radular features, do not always match with those based on protoconch characters. For example, Houbrick [4] placed Campaniloidea close to Cerithioidea based on similarity in their radulae whereas Bandel [3] erected two different clades for them based on significant differences in their protoconchs. Moreover, Bandel [3] kept forms with lecitho- and planktotrophic development in the same family/subfamily with the belief that lecithotrophic development is an apomorphy. In a more conventional classification, summarised in Bouchet and Rocroi [5], Turritellidae is an important family of the superfamily Cerithioidea. However, they did not rank taxonomic categories higher than superfamily and included Cerithioidea 
in the unranked clade Sorbeoconcha and still higher clade Caenogastropoda. In a recent phylogenetic analysis based on the largest set of morphological and molecular data so far, Strong et al. [6] demonstrated monophyly of the superfamily Cerithioidea and families like Turritellidae, Siliquariidae, and Potamididae and included these families in this superfamily. However, monophyly of the family Cerithiidae remains ambiguous in their study.

Allmon [7], in a significant contribution on turritellids, weighed the importance and stability of morphological characters, which have traditionally been used in turritellid taxonomy, such as the nature of the protoconch, the ontogeny of spiral ribs, the trajectory of growth lines, and the whorl profile [8]. He found the sequence of development of spiral ribs the most stable and usable character. Palaeontologists often struggle to find any of these characters, except whorl profile, to remain preserved satisfactorily in their specimens. Difficulty in taxonomic identification of fossil cerithioids owing to large intraspecific variation, strong convergence in morphology, and inadequate preservation of diagnostic characters has generally been appreciated in the literature [1-3].

Most of the cerithioid families are known by planktotrophic larvae and many Recent species have wide geographical distribution $[1,3]$. Living taxa belonging to the family Potamididae, mostly known from tropical mangrove swamps and marshes [2], are lecithotrophic whereas fossil representatives of the family were planktotrophic [3]. It is expected, having planktotrophic larvae, fossil cerithioids were also able to disperse widely.

The Tethys Realm housed a lot of cerithioids during the Palaeogene [9-11]. The Kutch basin of Gujarat, India, falls in the eastern border of the Indo-African Region for the Upper Eocene (sensu Popov [12]) and Western Tethys Region for the Oligocene (sensu Harzhauser et al. [13]). The Lower Palaeogene succession of Kutch is dominated by barren shale in the early part and foraminiferal limestone in the later part. A few limestone and marl layers in the early shale-dominated part, however, yielded a lot of fossils, mainly molluscs, whereas the foraminiferal limestone sparsely yielded megainvertebrates. Kutch molluscs are relatively better known only from the Oligocene and the Miocene [14-19]. PreOligocene forms are poorly recorded so far except a few recent reports [20-24]. A few shell beds in the lower Middle Eocene sequence accommodate the majority of the preOligocene fauna. Cerithioids are relatively less abundant here. The specimens are mostly found as internal molds. None of these representatives of this important group of gastropods has so far been reported. In this paper, we aim to record cerithioid species from the pre-Oligocene succession of Kutch as comprehensibly as possible in spite of their preservational inadequacy. We incorporate here representatives of the families like Turritellidae, Siliquariidae, Potamididae, and Cerithiidae. All these families are included in the superfamily Cerithioidea by Bouchet and Rocroi [5] and Strong et al. [6] whereas Turritellidae and Siliquariidae are not part of this superfamily in Bandel's [3] classification. Here, we follow the more conventional former scheme because it is supported by the phylogenetic analysis based on the largest set of data gathered solinebreak far [6].

The contemporaneous marine deposits from different parts of Pakistan have been known globally to yield a rich mollusc fauna including many cerithioids [25-35]. Because of geographical proximity the Kutch basin fauna has long been clubbed with the Pakistan fauna in the same palaeobiogeographical province without a critical assessment of the former. As a part of making a comprehensive understanding of the pre-Oligocene mollusc fauna from Kutch we undertake the study of systematics and palaeobiogeography of cerithioids. We analysed the distribution pattern of the pre-Oligocene cerithioid species from Pakistan and, on that backdrop, compared the distribution of the cerithioid fauna from Kutch.

\section{Geological Setting}

The Cenozoic formations of Kutch occur along the present coast line in an arcuate outcrop (Figure 1). These rocks unconformably overlie the Deccan Traps and the Mesozoic sedimentary rocks and are tectonically less disturbed. Biswas [36] classified this sequence into eight lithostratigraphic units: the Matanomadh Formation, the Naredi Formation, the Harudi Formation, the Fulra Limestone, the Maniyara Fort Formation, the Khari Nadi Formation, the Chhasra Formation, and the Sandhan Formation in ascending order.

Marine sedimentation was initiated in the Kutch basin with the Upper Palaeocene-Lower Eocene Naredi Formation, which was followed up by the lower Middle Eocene Harudi Formation. Both these units are argillaceous and are composed mostly of gypseous shale interspersed with layers of concretions. Two foraminiferal limestone beds characterize these two formations: Assilina limestone in the Naredi Formation and "Nummulites obtusus" bed in the Harudi Formation [36]. Molluscs and other larger invertebrates are sparsely present in the Naredi Formation whereas the Harudi Formation yields a lot of invertebrate fossils, mainly molluscs. Fossils come mainly from a few mollusc rich shell concentrations, which are persistent over a large area and occur in the lower part of the Harudi Formation (Figure 2). Sometimes the shell concentrations are associated with carbonate concretions. Tandon [37] called this fossiliferous horizon the Corbula subexarata Zone.

\section{Material and Methods}

The specimens have been collected from two localities of the Harudi Formation: (1) Loc. 1: the type section of the formation about $2 \mathrm{~km}$ north of village Harudi $\left(23^{\circ} 32^{\prime} \mathrm{N}\right.$, $68^{\circ} 40^{\prime} 52^{\prime \prime} \mathrm{E}$ ) and (2) Loc. 2: about $3 \mathrm{~km}$ northwest of village Nareda $\left(23^{\circ} 35^{\prime} 03^{\prime \prime} \mathrm{N}, 68^{\circ} 36^{\prime} 40^{\prime \prime} \mathrm{E}\right.$ ) (Figure 1). All the specimens are deposited in the Department of Geology, Presidency University, Kolkata. Plasticine casts are prepared from external molds for photography. Other specimens are coated with magnesium oxide before photography. 


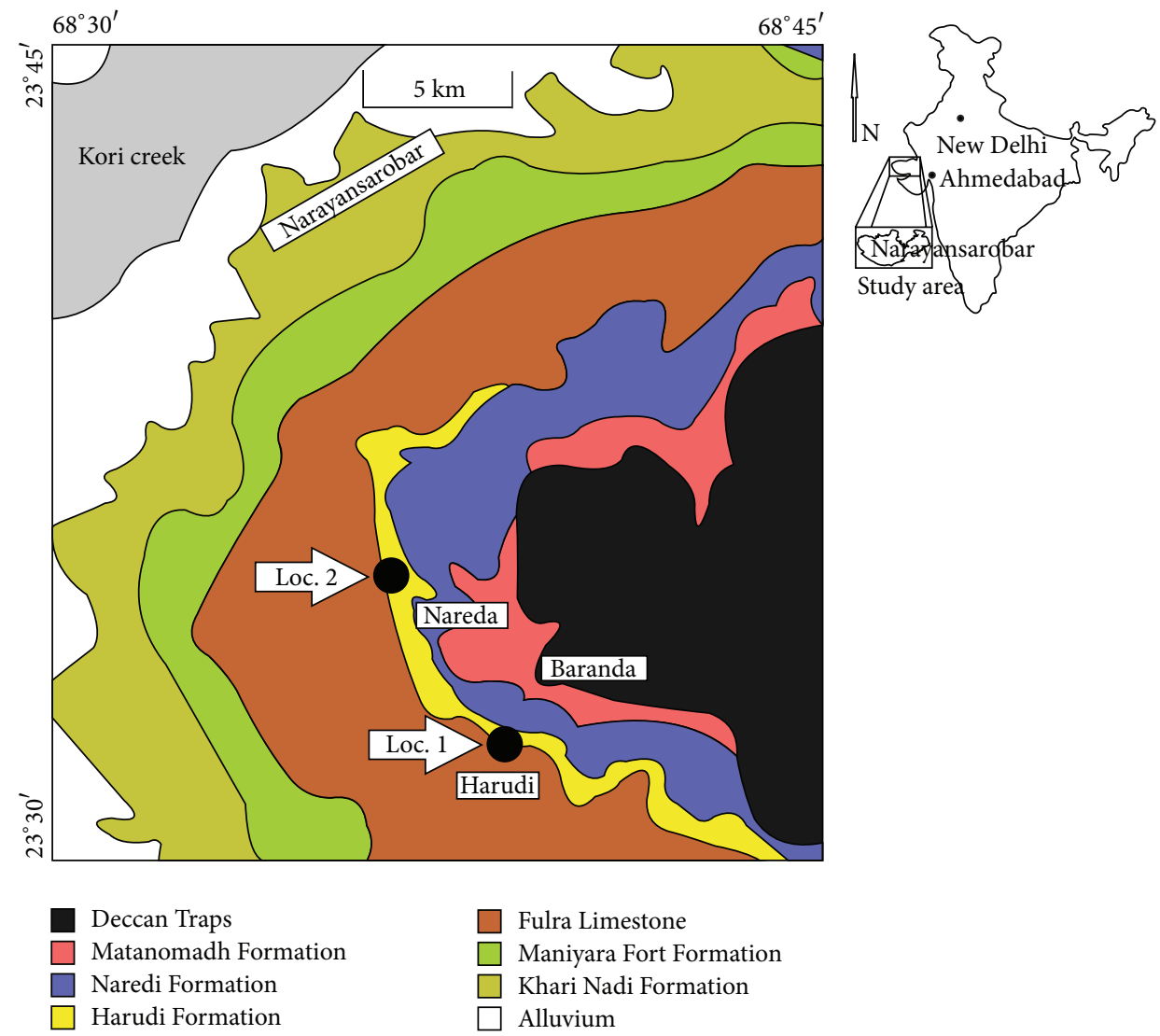

FIgURE 1: Geological map of a part of the Cenozoic exposures of Kutch with fossil localities (modified after Biswas, 1992).

\section{Systematic Palaeontology}

Superfamily: Cerithioidea Fleming 1822.

Family: Turritellidae Lovén 1847.

Genus: Palmerella Allmon 1996.

Type species: Turritella mortoni Conrad 1830.

Palmerella kutchensis n. sp.

(Figures 3(a)-3(i)).

Etymology. The species name is after the district of Kutch, Gujarat, from where this is reported.

Type Material. Holotype: PG/K/Cr 8, apex broken, with original shell; paratypes: $\mathrm{Pg} / \mathrm{K} / \mathrm{Cr}$ 9, 20, 25, 26, 27, 29, and 33, majority with original shell and the rest internal molds, apical part mostly broken.

Other Material. 25 more specimens, some internal molds, and the rest with original shell; apical part broken in most of the specimens.

Type Locality, Horizon, and Age. About $2 \mathrm{~km}$ north of village Harudi $\left(23^{\circ} 32^{\prime} \mathrm{N}, 68^{\circ} 40^{\prime} 52^{\prime \prime} \mathrm{E}\right)$ (Figure 1), Harudi Formation, lower Middle Eocene.

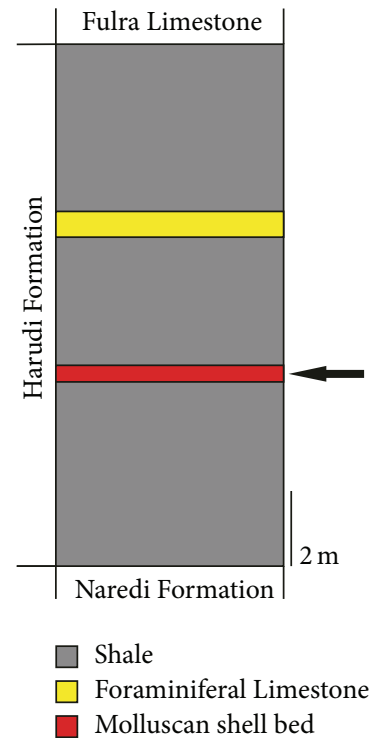

FIGURE 2: Generalized lithostratigraphic section of the Harudi Formation. Arrow marks the layer from where specimens were collected.

Diagnosis. Turreted, anomphalous shell; convex whorl side bearing characteristic turritelline spiral ribs; " $\mathrm{B}$ " and " $\mathrm{C}$ " stronger than "A", secondary spiral " $\mathrm{t}$ " of primary-like 
strength; growth line with deep sinus at middle of whorl, flex back at anterior part and nearly straight at base.

Description. Shell turreted, maximum reconstructed height about $60 \mathrm{~mm}$, maximum diameter observed $8 \mathrm{~mm}$, number of whorls 11, advolute, anomphalous, holostomatous; whorl side convex, base slightly convex, suture impressed; spiral angle small acute; aperture elliptical, its major axis almost parallel to coiling axis; surface almost smooth in internal mold; shell surface bears four narrow, sharp fundamental turritelline spiral ribs: " $\mathrm{B}$ " and " $C$ " stronger than " $A$ " and " $D$ ", " $\mathrm{B}$ " lies at mid-whorl and " $\mathrm{D}$ " marks the border between whorl side and base; secondary spiral " $t$ " between " $B$ " and "C" often of strength comparable to primary ribs; secondary "r," "s," and "u" strongly vary in strength; tertiary ribs of variable number and strength observed mainly posterior to "A"; base generally ornamented by few weak spiral ribs; collabral growth line with deep sinus at mid-whorl, growth line curves back to become straight and parallel to coiling axis beyond " $\mathrm{C}$ " in anterior and also curves back slightly in posterior side, at base almost straight; whorl profile convex; labral profile prosocline; shell thin.

Discussion. Allmon [7] erected the genus Palmerella to include American Palaeogene turritellids from the Gulf Coastal Plain with the spiral rib sequence of $\mathrm{C}_{1} \mathrm{~B}_{1} \mathrm{~A}_{2}$, growth line with a moderately deep lateral sinus flanked by two inflection points and a moderately deep basal sinus, relatively short protoconch, and basally carinate to rounded whorl profile. All these characters, however, appear to vary considerably in different species of the genus. The present species is placed in this genus with some reservations. The whorl outline and the lateral part of the growth line of the Kutch species match well with those of the genus. Instead of a basal sinus of the genus the Kutch species is characterized by almost straight growth line at the base. The protoconch characters and the sculpture formula of the species cannot be ascertained because of the lack of specimens with wellpreserved original shell in the earliest ontogenetic stage. However, as far as can be figured out the sculpture formula appears to be similar to that of the genus. The species can be compared to genera like Haustator and Torquesia. The genus Haustator differs from Palmerella in having sculpture formula of $\mathrm{C}_{1} \mathrm{~B}_{2} \mathrm{~A}_{3}$, a prominent basal carina and generally a frustrate whorl section with flat whorl side. The genus Torquesia is close to Haustator in having the same sculpture formula and a similar lateral sinus but differs in having a prominent adapical carina and beaded ribs. Allmon [7] apparently gave more weightage on sculpture formula and questioned the validity of Torquesia, which differs from Haustator only in ornamental features. The Kutch species differs from these genera in whorl profile and the nature of growth line in the basal part. The latter species also does not have any beaded ribs.

Eames [31] reported two Stiracolpus species from the Eocene of Pakistan: S. pakistanica Eames 1952 and S. hernaiensis (Cox 1931). Both are comparable to the new Kutch species in many respects. The former, however, differs in having three prominent equidistant spiral ribs on its whorl side whereas the present species is characterized by secondaries and tertiaries besides the fundamental turritelline primary ribs. S. hernaiensis has beaded primaries on its whorl side in early ontogeny [31]. Such beads are absent in P. kutchensis. The adult whorls of $S$. hernaiensis are characterized by three primaries and variable number of secondaries. However, there are only faint threads between " $\mathrm{B}$ " and " $\mathrm{C}$ " in the Pakistan species whereas " $\mathrm{t}$ " in the Kutch species is often as strong as the primaries. The whorl side is also slightly more convex in our species. These two Pakistan species and the Kutch species resemble the genus Stiracolpus very closely, especially in the general pattern of growth line (Figure 10 in Marwick [8]). The latter character has been given a lot of weightage by Marwick [8] although he observed significant convergence in its evolution. He did not consider the Pakistan species as Stiracolpus because of long gaps in their temporal and geographical distributions from the much younger Neogene genus from Australia and New Zealand.

\section{Measurements. See Table 1.}

Palmerella ranikoti (Vredenburg 1928b).

(Figures 3(j)-3(q)).

1909. Turritella angulata Sowerby, Cossmann and Pissarro, p. 59, pl. 6, Figures 3, 4, and 5.

1928. T. ranikoti Vredenburg p. 58-59, pl. 5, Figure 8.

Material. Nine internal molds (PG/K/Cr 55-62, 64) and 4 external molds (PG/K/Cr 63, 65-67), mainly of juvenile whorls.

Description. Shell small, slender, and turreted and consists of about 15 whorls; whorls widening slowly, depressed; suture prominently impressed; spiral angle narrow acute; whorl side convex with somewhat angular anterior margin in internal mold in early ontogeny, with a spiral ridge near mid-whorl in later whorls; in artificial casts from external molds surface characterized by a sharp, projected keel in the anterior part, sometimes summit of keel granulated, above keel surface flat to slightly concave with 2 prominent fine spiral ridges, and a few faint lines above and below the keel; keel slightly turned up posteriorly; growth line trajectory, aperture, and basal features not known.

Discussion. The species is tentatively placed in the genus Palmerella as its whorl profile resembles P. mortoni, the type species, most closely including a sharp projected keel in the anterior part. Protoconch characters, growth line trajectory, and sequence of appearance of spiral ribs are not known for this species. The present species resembles Turritella ranikoti Vredenburg in almost all respects, being slender, having strong sharply projecting keel in the anterior part and similar pattern of ornamentation, and is considered conspecific. Minor differences include somewhat concave and more inclined surface posterior to the keel and more projected upturned keel in the Kutch form than in the Pakistan types recorded from the Palaeocene by Cossmann and Pissarro [26], Vredenburg [38], Cox [28], and Iqbal [34]. This report extends the temporal distribution of the species 
TABLE 1: Measurements of selected types of Palmerella kutchensis n. sp. Reconstructed measurements are indicated by "c."

\begin{tabular}{llcc}
\hline Sp. number & Type & Diameter $(\mathrm{mm})$ & Height $(\mathrm{mm})$ \\
\hline PG/K/Cr 8 & Holotype & 15.43 & $\mathrm{c} 55.5$ \\
PG/K/Cr 9 & Paratype & 12.69 & $\mathrm{c} 42.8$ \\
PG/K/Cr 10 & Topotype & 15.02 & 42.11 \\
PG/K/Cr 14 & Topotype & 10.31 & $\mathrm{c} 31.5$ \\
PG/K/Cr 15 & Topotype & 10.92 & $\mathrm{c} 37.8$ \\
PG/K/Cr 16 & Topotype & 8.88 & $\mathrm{c} 28.8$ \\
PG/K/Cr 17 & Topotype & 10.11 & $\mathrm{c} 31.8$ \\
PG/K/Cr 18 & Topotype & 8.7 & $\mathrm{c} 25.6$ \\
PG/K/Cr 19 & Topotype & 7.43 & $\mathrm{c} 23.6$ \\
PG/K/Cr 20 & Paratype & 15.27 & $\mathrm{c} 51.66$ \\
PG/K/Cr 21 & Topotype & 11.95 & $\mathrm{c} 42.1$ \\
PG/K/Cr 22 & Topotype & 10.96 & $\mathrm{c} 33.2$ \\
PG/K/Cr 23 & Topotype & 12.10 & $\mathrm{c} 40$ \\
PG/K/Cr 24 & Topotype & 9.37 & 30.25 \\
PG/K/Cr 25 & Paratype & 11.15 & $\mathrm{c} 34.2$ \\
PG/K/Cr 26 & Paratype & 11.86 & $\mathrm{c} 36.69$ \\
PG/K/Cr 27 & Paratype & 7.45 & $\mathrm{c} 25.3$ \\
PG/K/Cr 28 & Topotype & 6.93 & $\mathrm{c} 20.5$ \\
PG/K/Cr 29 & Paratype & 5.23 & $\mathrm{c} 14.5$ \\
PG/K/Cr 30 & Topotype & 5.56 & 15.23 \\
PG/K/Cr 31 & Topotype & 7.2 & $\mathrm{c} 21.75$ \\
PG/K/Cr 32 & Topotype & 6.35 & $\mathrm{c} 17.1$ \\
PG/K/Cr 38 & Topotype & 9.31 & $\mathrm{c} 20.40$ \\
PG/K/Cr 39 & Topotype & 7.50 & \\
\hline
\end{tabular}

to the lower Middle Eocene. Iqbal [34], however, mentioned that its distribution extends to the Miocene without citing any reference to locality.

Measurements. See Table 2.

Genus: Haustator Montfort 1810.

Type species: Turritella imbricataria Lamarck 1804.

Haustator? punjabensis Eames 1952.

(Figure 3(r)).

Material. Single incomplete specimen (PG/K/Cr 4), internal mold.

Description. Shell small, turreted, slowly widening, and anomphalous; apical whorls missing; whorl side flat with a shallow keel near anterior border, below which is rounded; whorl profile somewhat imbricate; suture impressed, narrow; base convex, marked by a wide and blunt ridge running through its middle; whorl surface in internal mold bears faint spiral ribs, one in the middle keel-like and almost as strong as the anterior keel; a third keel, visible in last whorl, at a position corresponding to anterior suture of previous whorl.

Discussion. The whorl profile of the species with flat whorl side and anterior keel is of the genus Haustator. Other
TABLE 2: Measurements of selected specimens of Palmerella ranikoti (Vredenburg 1928) [38]. Reconstructed measurements are indicated by "c."

\begin{tabular}{lcc}
\hline Sp. number & Diameter $(\mathrm{mm})$ & Height $(\mathrm{mm})$ \\
\hline PG/K/Cr 55 & 12.48 & 35.42 \\
PG/K/Cr 56 & 7 & $\mathrm{c} 27.3$ \\
PG/K/Cr 57 & 7.4 & $\mathrm{c} 25.42$ \\
PG/K/Cr 58 & 8.74 & $\mathrm{c} 30$ \\
PG/K/Cr 59 & 6.56 & $\mathrm{c} 21.8$ \\
PG/K/Cr 60 & 5.07 & $\mathrm{c} 16.7$ \\
PG/K/Cr 61 & 3.4 & 7.6 \\
PG/K/Cr 62 & 10.06 & $\mathrm{c} 34.6$ \\
PG/K/Cr 63 & 3.19 & 8.11 \\
PG/K/Cr 65 & 11.85 & $\mathrm{c} 34.9$ \\
PG/K/Cr 66 & $\mathrm{c} 11.5$ & $\mathrm{c} 34.38$ \\
PG/K/Cr 67 & 5.54 & 15.3 \\
\hline
\end{tabular}

diagnostic characters such as those of the protoconch, growth line, and ontogenetic development of ornamentation cannot be observed.

The Kutch form resembles Turritella (Haustator?) punjabensis Eames 1952 from the Lower Eocene of Pakistan in all observable features such as whorl profile and ornamental pattern and is considered conspecific. The author of the species was in doubt in placing it in Haustator. We only have one incompletely preserved specimen from Kutch and many diagnostic characters of the genus cannot be studied in it. Hence, we refrain from putting the species on any firmer ground. Contemporaneous $H$. imbricataria is a widespread species and known from Pakistan [31]. It differs from H.? punjabensis in being larger and having a wide flat whorl side posterior to the anterior keel. Further, its whorl side is ornamented by a series of similar spiral ribs.

Measurements. Diameter $10.65 \mathrm{~mm}$; reconstructed height $40 \mathrm{~mm}$.

Family: Siliquariidae Anton 1838.

Genus: Tenagodus Guettard 1770.

Type species: Serpula anguina Linnaeus 1758 (by subsequent designation).

Tenagodus? sowerbyi $\mathrm{n}$. sp.

(Figures 3(s)-3(u)).

Etymology. After J. de C. Sowerby, the first to report Cenozoic molluscs from Kutch.

Type Material. Holotype: $\mathrm{PG} / \mathrm{K} / \mathrm{Cr} 1$, internal mold; paratypes: PG/K/Cr 2 and 3, mainly internal mold; $\mathrm{Cr} 2$ with partially preserved shell.

Type Locality, Horizon, and Age. About $2 \mathrm{~km}$ north of village Harudi $\left(23^{\circ} 32^{\prime} \mathrm{N}, 68^{\circ} 40^{\prime} 52^{\prime \prime} \mathrm{E}\right)$ (Figure 1), Harudi Formation, lower Middle Eocene. 


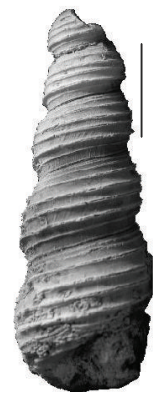

(a)

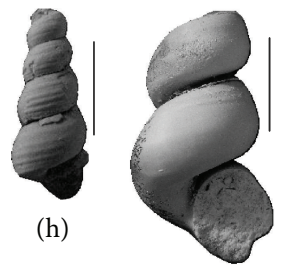

(i)

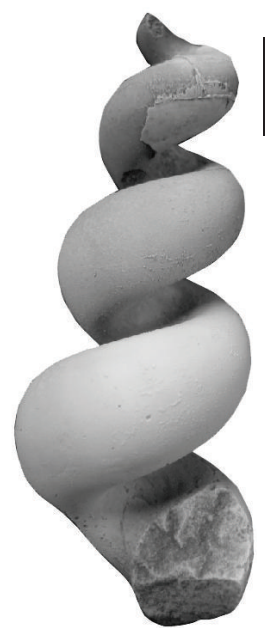

(s)

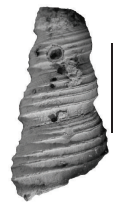

(b)

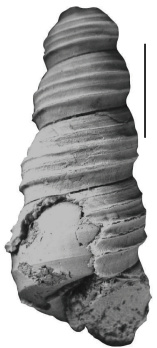

(c)

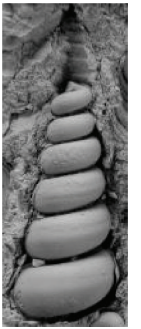

(j)

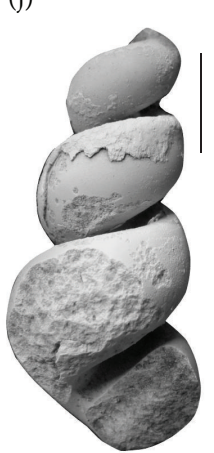

(t)

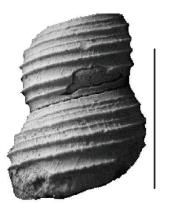

(d)

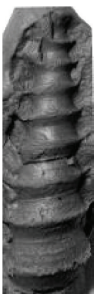

(k)

(1)

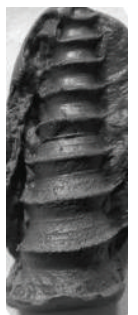

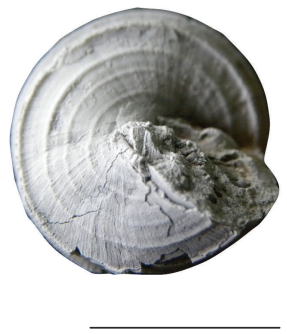

(e1)

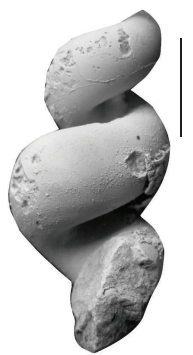

(u)

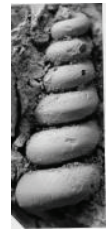

(m)

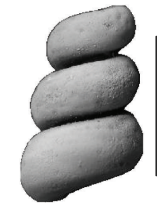

(n)

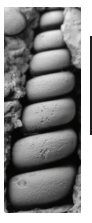

(v)

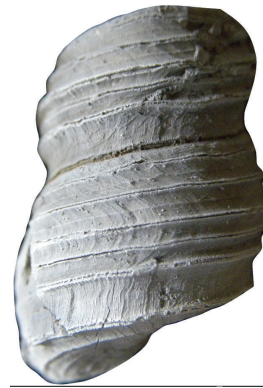

(e2)

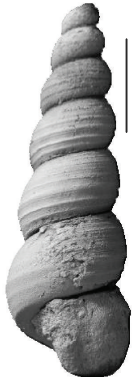

(f)

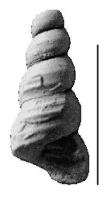

(g)

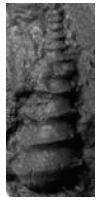

(o)

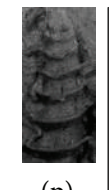

(p)

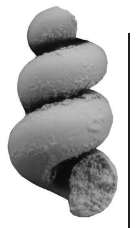

(q)

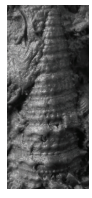

(z)

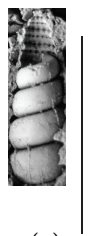

(x)

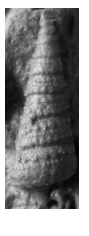

(y)

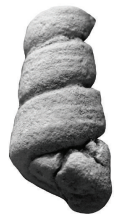

(r)

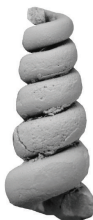

(w)

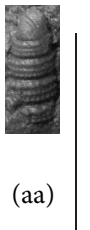

(aa)

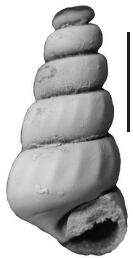

(ab)

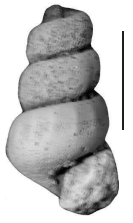

(ac)

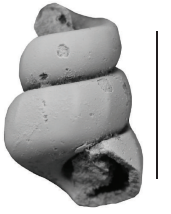

(ad)

Figure 3: (a)-(i) Palmerella kutchensis n. sp.: apertural view of holotype PG/K/Cr 8 (a), abapertural view of paratype PG/K/Cr 25 (b), apertural view of paratype PG/K/Cr 20 (c), closeup view of paratype PG/K/Cr 26 (d), basal (e1) and lateral (e2) views in closeup of topotype PG/K/Cr 35 , apertural view of paratype PG/K/Cr 9 (f), apertural view of paratype PG/K/Cr 29 (g), apertural view of paratype PG/K/Cr 27 (h), and apertural view of paratype PG/K/Cr 33 (i). (j)-(q) Palmerella ranikoti (Vredenburg 1928b): abapertural views of PG/K/Cr 55 (j), PG/K/Cr 66 (k), PG/K/Cr 65 (l), PG/K/Cr 62 (m), PG/K/Cr 58 (n), PG/K/Cr 67 (o), and PG/K/Cr 63 (p); apertural view of PG/K/Cr 60 (q). (r) Haustator? punjabensis (Eames 1952): apertural view of PG/K/Cr 4. (s)-(u) Tenagodus? sowerbyi $\mathrm{n}$. sp.: apertural views of holotype PG/K/Cr 1 (s) and paratypes PG/K/Cr $2(\mathrm{t})$ and PG/K/Cr $3(\mathrm{u})$. (v)-(aa) Potamides archiaci n. sp.: abapertural view of holotype PG/K/Cr 41 (v), apertural view of paratype PG/K/Cr 42 (w), and abapertural views of paratypes PG/K/Cr 45 (x), PG/K/Cr 47 (y), PG/K/Cr 48 (z), and PG/K/Cr 49 (aa). (ab)-(ad) Cerithium harudiensis n. sp.: apertural views of holotype PG/K/Cr $5(\mathrm{ab})$ and paratypes PG/K/Cr 6 (ac) and PG/K/Cr 7 (ad). Scale bar $=10 \mathrm{~mm}$.

Diagnosis. Medium sized; few convex tube-like whorls; whorls not in contact; aperture elliptical.

Description. Size medium, four tube-like whorls; coiling loose and open, only slightly irregular, dextral; whorls not in contact, whorl side convex, columellar side of whorls flatter, base rounded; aperture elliptical, its major axis inclined towards coiling axis, labral profile not known; shell surface smooth; no trace of septa, shell slit or holes observed.

Discussion. The species is comparable to contemporaneous species like Tenagodus striatus (Defranc 1827) and T. sulcatus (Defrance 1843) from France in general shape. However, both the French species have prominent spiral ribs whereas 
the Kutch species is smooth. T. striatus also has more open and looser coiling than T.? sowerbyi n. sp. (pl. 22, Figures 4-6 in Cossmann [39]; pl. 22, Figure 132-1 in Cossmann and Pissarro [9]). It also uncoils rapidly after a few whorls to become long and almost straight. Coiling in the Kutch species is only slightly irregular and never becomes straight. Both the French species bear shell slits, which in early ontogeny become more or less regular series of holes narrowed by lateral growth. The Kutch species is chiefly represented by internal molds and does not show this character.

The only Tenagodus species known from Kutch so far, T. granti Sowerby 1840, comes from the Oligocene and the Miocene [14, 17, 40, 41]. The holotype of the species reported by Sowerby from the Lower Miocene [14] differs considerably from the new species reported here in having distinctly more irregular coiling, prominent slit constituted of series of pores, and transverse fractures in the shell. The Oligocene representative of T. granti reported from Kutch by Harzhauser et al. [17] has much less irregularity in the coiling than that in its holotype and its whorls are in contact. Slit with pores and transverse fractures of the shell, which characterize the Sowerby's type and the genus (see Bieler [42]), are also not clear in the photograph provided by Harzhauser et al. [17]. However, T.? sowerbyi n. sp. differs from this Oligocene form in having much fewer whorls. The whorls in the latter are also more depressed than in the former.

The new species is placed in the genus Tenagodus based on shape and coiling and on stratigraphical and geographical considerations. The species is also comparable to the genus Laxispira Gabb 1877 in having open but regular coiling and rounded whorl section. Laxispira, however, lacks shell slit and is known by slightly beaded spiral ribs and is restricted to the Upper Cretaceous. L. lumbricalis Gabb 1877, the type species from the USA, is smaller than the present species and has prominent spiral ribs (Pl. 55, Figures 5, 8 in Wade [43]; Pl. 7, Figures 3-5 in Sohl [44]). However, its internal mold is likely to be smooth. The Kutch species, where original shell is preserved, does not show any suggestion of shell slit or pores. The shell is preserved only in a small portion of early ontogeny. In Tenagodus, slit of earlier whorls often gets closed [42]. If, however, the absence of slit in the Kutch species is real it should belong to Laxispira. This report then will extend the geographical and stratigraphical ranges of the latter.

Measurements. See Table 3.

Family: Potamididae H. Adams and A. Adams 1854.

Genus: Potamides Brongniart 1810.

Type species: Potamides lamarckii Brongniart 1810.

Potamides archiaci n. sp.

(Figures 3(v)-3(aa)).

Etymology. After A. d'Archiac, one of the pioneering researchers to describe molluscs from the Indian subcontinent.

Type Material. Holotype: PG/K/Cr 41, internal mold; paratypes: PG/K/Cr 42 and 45, internal mold; PG/K/Cr 47, 48, and 49 , external mold.
TABLE 3: Measurements of Tenagodus? sowerbyi n. sp. Reconstructed measurements are indicated by "c."

\begin{tabular}{lccc}
\hline Sp. number & Type & Diameter $(\mathrm{mm})$ & Height $(\mathrm{mm})$ \\
\hline PG/K/Cr 1 & Holotype & 20.71 & 52.15 \\
PG/K/Cr 2 & Paratype & 19.7 & $\mathrm{c} 47$ \\
PG/K/Cr 3 & Paratype & 18.40 & $\mathrm{c} 42$ \\
\hline
\end{tabular}

Other Material. Three more internal molds and 2 more external molds.

Type Locality, Horizon, and Age. About $2 \mathrm{~km}$ north of village Harudi $\left(23^{\circ} 32^{\prime} \mathrm{N}, 68^{\circ} 40^{\prime} 52^{\prime \prime} \mathrm{E}\right.$ ) (Figure 1), Harudi Formation, lower Middle Eocene.

Diagnosis. Small, narrow, and high spired shell; whorl side and base flat; two prominent rows of spiral tubercles; strength of posterior tubercles increases more rapidly than anterior ones during ontogeny; other weaker rows of tubercles appear through ontogeny.

Description. Shell small, turreted, conical, narrow, and slowly widening; apical angle small, acute; about 15 whorls, whorls depressed; whorl side flat, relatively convex in internal mold; whorls separated by prominently impressed suture; base flat; aperture elliptical, inclination of its major axis towards coiling axis, labral profile not known; surface in earliest whorls marked only by a beaded angularity towards anterior side and a faint spiral row of closely spaced beads near posterior margin, within a few whorls surface becomes flat with two prominent spiral ribs carrying strong beads marking anterior and posterior margins; posterior beads thereafter become stronger tubercles and more distantly spaced than the anterior beads; a third spiral row of weaker beads occur in between the two; a fourth spiral row of faint beads appears later at the anterior-most end of the whorl.

Discussion. The species, judged from its shape, coiling pattern, and typical ornamentation, belongs to the genus Potamides. Potamides pascoei Cox 1931 from the Lower Eocene of Baluchistan, Pakistan, has two prominent spiral ribs bearing tubercles. The posterior tubercles are stronger and more distant than the anterior tubercles. The preserved earliest whorl in the figured Pakistan specimen shows almost equally strong tubercles in both the ribs. Since more apical whorls are not known it cannot be confirmed whether a transition in the relative strength of the posterior tubercles similar to that in the Kutch species occurred in it. However, the Pakistan species differs from the Kutch species in having two weakly tuberculated similar ridges in between the stronger anterior and posterior ribs whereas this space is occupied in the Kutch species by only one relatively weaker rib. The suture in the Baluchistan species is obscure whereas that in the Kutch form is prominent and impressed. Potamides durranus Iqbal 1969a from the Lower Eocene of Quetta, Pakistan, having convex whorl side, strong transverse varices, 
and feeble spiral lines perhaps does not belong to this genus (see Reid et al. [2]).

Measurements. See Table 4.

Family: Cerithiidae Fleming 1822.

Genus: Cerithium Bruguière 1789.

Type species: Cerithium erythraeonense Lamarck 1822.

Cerithium harudiensis $\mathrm{n}$. $\mathrm{sp}$.

(Figures 3(ab)-3(ad)).

Etymology. After the village Harudi, the type section of Harudi Formation, from where the species has been found.

Type Material. Holotype: PG/K/Cr 5; paratypes: PG/K/Cr 6 and 7; all internal molds.

Type Locality, Horizon, and Age. About $2 \mathrm{~km}$ north of village Harudi $\left(23^{\circ} 32^{\prime} \mathrm{N}, 68^{\circ} 40^{\prime} 52^{\prime \prime} \mathrm{E}\right)$ (Figure 1), Harudi Formation, lower Middle Eocene.

Diagnosis. Small, relatively wide shell; protoconch depressed; aperture elliptical; surface ornamented with 12-17 slightly curved transverse ribs.

Description.Shell small, turreted, narrow; protoconch strongly depressed; whorls depressed, whorl side convex in first three whorls, convexity decreases thereafter; suture impressed; spiral angle relatively large, acute; aperture elliptical with its axis inclined towards coiling axis, labral profile unknown; base slightly convex, boundary between base and whorl side well-marked; whorl surface bears closely spaced, slightly curved, anteriorly inclined transverse ribs; number of ribs vary considerably from 12 to 17 in a whorl; spacing, inclination, and strength of ribs show some irregularity; one specimen with shallow, concave forward, blunt transverse constrictions at slightly less than $360^{\circ}$ angular distance; basal surface with a striation through its middle.

Discussion. The genus Cerithium is extremely variable in terms of shell shape and ornamentation. Many species also show strong intraspecific variability [1]. Several other cerithioid genera have strongly overlapping morphological characters with Cerithium. Because we only have internal molds in our disposal important diagnostic characters, such as siphonal canal, are missing. In the absence of more diagnostic characters the present species is considered as Cerithium sensu lato based on its shape and prevailingly transverse ornamentation. Adjacent to the constrictions in each whorl of one of the Kutch specimens there occur thicker and blunter transverse ribs, which are reminiscent of cerithiid varices. The Kutch species shows considerable variability in ornamental features.

Cerithium baluchi Cox 1931 from the Lower Eocene of Baluchistan, Pakistan, has flatter whorl side, less impressed suture, and more distant ribs in later whorls than those in
TABle 4: Measurements of Potamides archiaci n. sp. Reconstructed measurements are indicated by "c."

\begin{tabular}{llcc}
\hline Sp. number & Type & Diameter $(\mathrm{mm})$ & Height $(\mathrm{mm})$ \\
\hline PG/K/Cr 40 & Topotype & c6.9 & c25 \\
PG/K/Cr 41 & Holotype & 5.9 & c24 \\
PG/K/Cr 42 & Paratype & 8.05 & $\mathrm{c} 31.22$ \\
PG/K/Cr 43 & Topotype & 7.11 & $\mathrm{c} 25$ \\
PG/K/Cr 45 & Paratype & c2.6 & c7.3 \\
PG/K/Cr 46 & Topotype & 3.2 & $\mathrm{c7.5}$ \\
PG/K/Cr 47 & Paratype & 3.77 & 9.03 \\
PG/K/Cr 48 & Paratype & 6.48 & 15.68 \\
PG/K/Cr 49 & Paratype & 3.35 & $\mathrm{c7.57}$ \\
PG/K/Cr 50 & Topotype & 3.82 & $\mathrm{c} 8.84$ \\
PG/K/Cr 51 & Topotype & 3.15 & 7.08 \\
\hline
\end{tabular}

the Kutch species. Also the ribs in the former are straighter and posteriorly thickened in tubercles. C. (Ptychocerithium) pseudocorrugatum d'Orbigny 1852 reported by Sowerby [14] from the Lower Miocene of Kutch is similar in many respects to the present Eocene species such as whorl outline, suture, and ribbing pattern. Absence of the original shell in our species did not allow the study of details of the spiral ornamentation, which is much finer than the transverse ribs in the younger species. Disparity in age of the two also inhibits their specific unity.

Measurements. See Table 5.

\section{Palaeobiogeography and Evolution}

A plethora of the Cenozoic fossils, mainly molluscs, are known from different parts of Pakistan [15, 16, 25-35, 38, $45,46]$. A diverse mollusc fauna is also known from the Cenozoic of Kutch [14-19, 21, 22, 47]. Majority of the Kutch molluscs have so far been reported from the OligoceneMiocene interval and are generally considered identical to one or another species of the Pakistan fauna. Faunas from Pakistan and western Indian basins have traditionally been considered together as the Indian fauna without much critical appreciation of these faunal compositions.

This Indian fauna, during the Early Palaeogene, is known to be related most closely to the contemporaneous east African fauna $[12,13,29]$. This Indo-African fauna had affinity to faunas from the Middle East countries also [28, 48]. Popov [12] believed that the Indo-African fauna did not have much similarity to the contemporaneous Mediterranean fauna from Europe. Our analysis of the Palaeocene and the Eocene molluscs from Pakistan based on Eames [30, 31] and Iqbal [32-34] did not reveal significant differences in similarity of this fauna with Africa and Europe. More importantly, this analysis reveals that this Pakistan fauna is composed mostly of endemic mollusc species. Out of 231 bivalve species reported by Eames [30] and Iqbal [32-34] only 34 are also known from outside Pakistan of which 15 are from India. Africa and Europe share 24 and 15 species, respectively, with Pakistan. Again, out of 233 gastropods 
TABle 5: Measurements of Cerithium harudiensis n. sp. Reconstructed measurements are indicated by "c."

\begin{tabular}{lccc}
\hline Sp. number & Type & Diameter $(\mathrm{mm})$ & Height $(\mathrm{mm})$ \\
\hline PG/K/Cr 5 & Holotype & 12.28 & 25.6 \\
PG/K/Cr 6 & Paratype & 11.6 & c24.7 \\
PG/K/Cr 7 & Paratype & 8.75 & c15 \\
\hline
\end{tabular}

reported by Eames [31] and Iqbal [32-34] from the Lower Palaeogene of Pakistan only 18 also occur outside Pakistan of which 8 are shared with India. Africa and Europe share only 9 and 11, respectively. An important feature of distribution of these molluscs in Pakistan is that majority of the species are restricted to a single locality or only a few localities. For example, faunal composition of Sind is significantly different from that of Baluchistan or North West Frontier Province [34].

The distribution of the cerithioid fauna from the Palaeocene and the Eocene of Pakistan reveals a similar picture. The cerithioid data has been collated from Cossmann and Pissarro [26], Vredenburg [38], Cox [28, 29], Eames [31], and Iqbal [32-34]. Only 3 out of 48 species were known from outside Pakistan, 2 of which have wide geographical and temporal distributions. Their geographical ranges include both African and European countries along with some from the Middle East. The other is known from the contemporaneous deposits of France. In this report we have recorded from Kutch two turritellid species known from Pakistan, thereby increasing the tally to 5 out of 48 . Again, 27 out of 48 species from Pakistan are known only from a single locality.

The six species that are reported here from Kutch show strong endemism. All but two are new species.

This high endemism of the Lower Palaeogene benthic molluscs in general and cerithioids in particular might have resulted from (i) low dispersal potentials of majority of the molluscs or (ii) restricted faunal mixing between these newly invaded basins. Test of the first possibility requires detailed information on protoconch morphology because dispersal of these benthic animals takes place primarily in their larvae. Molluscs with planktotrophic larvae have a higher dispersal potential than those with lecithotrophic larvae. However, actual dispersal is dependent on several other factors and a linear relation between larval development and geographical distribution may not always exist. No studies on the protoconch morphology of molluscs from Pakistan and India are available. The present study attempted to do one but could not succeed because of inadequate preservation of the original shell in the apical part. However, cerithioids are mostly known by planktotrophic larvae and wide geographical distribution [3]; hence, they oppose this possibility.

Marine sedimentation in Kutch started during the Cenozoic period in a distinctly paralic setting over an undulating substrate of the Deccan Traps and the Mesozoic sedimentary rocks. Plane laminated gypseous shales, deposited in a quiet water setting, dominate the Lower Palaeogene succession [23, 36]. Depth and dynamism, however, varied locally, especially in the early phase of deposition. Varied facies from crossbedded sandstone to shell beds of very restricted lateral and vertical extent to conglomerates develop locally (personal observation, see also Chattoraj et al. [49] and Garg et al. [50]). Evidences for deposition in a restricted, often reducing, setting of lagoon-marsh are aplenty, such as exploitable quantity of lignite, black shale, evaporite, and limonite pseudomorph after pyrite $[36,51,52]$. Water circulation in such a restricted basin was obviously restricted until a sustained open marine condition started to prevail from the later part of the Middle Eocene with the deposition of foraminiferal limestone.

The Cenozoic marine sedimentary succession at different parts of Pakistan started with a paralic setting during the Palaeocene (Vredenburg in $[26,34]$ and references therein). During the Early and Middle Eocene Pakistan basins, however, were already receiving sediments of the more open shallow shelf setting ([34] and references therein). Harzhauser et al. [13] demonstrated an easterly ocean current travelling from the Mediterranean Region (sensu Popov [12]) that swept the shores of Pakistan and western India during the Late Eocene time (text Figure 3 in Harzhauser et al. [13]). The Indian and Pakistan basins perhaps derived their faunas from western parts of the Tethys Realm if a similar current persisted since the Palaeocene. Iqbal $[32,33]$ observed that several of the common components of the mollusc faunas from the Mediterranean and Pakistan occur in older stratigraphic levels in the latter area than in the former but emphasized the absence of any evidence for the migration of the Lower Palaeogene fauna of Pakistan towards west. High endemism of the Indian and Pakistan basins, however, suggests that early invaders evolved rapidly in these basins and developed into a distinct provincial fauna. Further, within the province, circulation and hence faunal mixing was restricted in the Early Palaeogene period resulting in rather localized distribution of most of the species.

The Lower Palaeogene mollusc fauna of Kutch was apparently derived from the Pakistan fauna. So far, we have studied corbulids [24], oysters, and some venerid bivalves (unpublished data) and cerithioids (this study), and some conid, volutid, and naticid gastropods (unpublished data) from the Lower Palaeogene of Kutch. Many of these species have comparable and sometimes identical representatives in Pakistan. This similarity puts the Kutch fauna in the same palaeobiogeographical province with Pakistan. But mixing with the Pakistan fauna was not regular and intense because of the restricted nature of the Kutch basin. This is quite apparent from the facies the Kutch basin was receiving in its early history. The Kutch fauna, constituted largely of endemic species, evolved independently in isolation.

In contrast to the restricted nature of the mollusc species the genera show rather wide distribution. All the valid cerithioid genera recorded from the Indian subcontinent including those in this report are known from Europe and Africa. The genus Palmerella was known only from southeastern North America. But its absence in Europe or Africa may be due to the absence of recent systematic revisions of the faunas from these areas [7]. Other contemporaneous mollusc genera from Pakistan and western India were also quite widespread (see also Halder [23] and Halder and Bano [24]). 


\section{Conflict of Interests}

The authors declare that there is no conflict of interests regarding the publication of this paper.

\section{Acknowledgment}

The first author received financial support from the Department of Science and Technology, India (Project no. SR/S4/ES653/2012).

\section{References}

[1] R. S. Houbrick, "Monograph of the genus Cerithium Bruguiere in the Indo-Pacific (Cerithiidae: Prosobranchia)," Smithsonian Contributions to Zoology No. 510, 1992.

[2] D. G. Reid, P. Dyal, P. Lozouet, M. Glaubrecht, and S. T. Williams, "Mudwhelks and mangroves: the evolutionary history of an ecological association (Gastropoda: Potamididae)," Molecular Phylogenetics and Evolution, vol. 47, no. 2, pp. 680699, 2008.

[3] K. Bandel, "Families of the Cerithioidea and related superfamilies (Palaeo-Caenogastropoda; Mollusca) from the Triassic to the Recent characterised by protoconch morphology-including the description of new taxa," Freiberger Forschungshefte C: Paläontologie, Stratigraphie, Fazies, vol. 511, no. 14, pp. 59-138, 2006.

[4] R. S. Houbrick, "Cerithioidean phylogeny," Malacological Review, supplement 4, pp. 88-128, 1988.

[5] P. Bouchet and P. G. Rocroi, "Classification and nomenclature of gastropod families," Malacologia, vol. 47, no. 1-2, pp. 1-397, 2005.

[6] E. E. Strong, D. J. Colgan, J. M. Healy, C. Lydeard, W. F. Ponder, and M. Glaubrecht, "Phylogeny of the gastropod superfamily Cerithioidea using morphology and molecules," Zoological Journal of the Linnean Society, vol. 162, no. 1, pp. 43-89, 2011.

[7] W. D. Allmon, Systematics and Evolution of Cenozoic American Turritellidae (Mollusca: Gastropoda) I: Paleocene and Eocene Coastal Plain Species Related to "Turritella Mortoni Conrad" and "Turritella Humerosa Conrad", vol. 59 of Palaeontographica Americana, Paleontological Research Institution, 1996.

[8] J. Marwick, "Gereric revision of the Turritellidae," Proceedings of the Malacological Society of London, vol. 32, pp. 144-166, 1957.

[9] M. Cossmann and G. Pissarro, Iconographie complète des coquilles fossiles de l'Éocene des environs de Paris, vol. 2 of Scaphopodes Gastropodes Brachiopodes Céphalopodes \& Supplement, 1910-1913.

[10] G. Piccoli, S. Sartori, A. Franchino, R. Pedron, L. Claudio, and A. R. Natale, "Mathematical model of faunal spreading in benthic palaeobiogeography (applied to Cenozoic Tethyan molluscs)," Palaeogeography, Palaeoclimatology, Palaeoecology, vol. 86, no. 1-2, pp. 139-196, 1991.

[11] J. Leloux and F. P. Wesselingh, "Types of Cenozoic Mollusca from Java in the Martin collection of Naturalis," Nationaal Natuurhistorisch Museum Technical Bulletin, vol. 11, pp. 1-765, 2009.

[12] S. V. Popov, "Zoogeography of the Upper Eocene basins of Western Eurasia based on bivalve molluscs," Stratigraphy and Geological Correlation, vol. 2, pp. 103-118, 1993.

[13] M. Harzhauser, W. E. Piller, and F. F. Steininger, "CircumMediterranean Oligo-Miocene biogeographic evolution-the gastropods' point of view," Palaeogeography, Palaeoclimatology, Palaeoecology, vol. 183, no. 1-2, pp. 103-133, 2002.

[14] J. C. Sowerby, "Fossils from the Tertiary formations, Cutch," Transactions of the Geological Society of London 2, vol. 5, pp. 2526,1840 .

[15] E. Vredenburg, "Descriptions of Mollusca from the post-Eocene Tertiary formation of north-western India: Cephalopoda, Opisthobranchiata, Siphonostomata," Memoirs of the Geological Survey of India, vol. 50, no. 1, pp. 1-350, 1925.

[16] E. Vredenburg, "Description of Mollusca from the post-Eocene Tertiary formation of north-western India: Gastropoda (in part) and Lamellibranchiata," Memoirs of the Geological Survey of India, vol. 50, no. 2, pp. 351-506, 1928.

[17] M. Harzhauser, M. Reuter, W. E. Piller, B. Berning, A. Kroh, and O. Mandic, "Oligocene and Early Miocene gastropods from Kutch (NW India) document an early biogeographic switch from Western Tethys to Indo-Pacific," Paläontologische Zeitschrift, vol. 83, no. 3, pp. 333-372, 2009.

[18] K. G. Kulkarni, S. Bhattacharjee-Kapoor, and V. D. Borkar, "Molluscan fauna from the Miocene sediments of Kachchh, Gujarat, India: part 3: gastropods," Journal of Earth System Science, vol. 119, no. 3, pp. 307-341, 2010.

[19] R. P. Kachhara, R. L. Jodhawat, and K. Bigyapati Devi, “Lower Oligocene bivalves of Ramanian Stage from Kachchh, Gujarat, India," Journal of Earth System Science, vol. 121, pp. 405-438, 2012.

[20] K. K. Tandon and D. K. Srivastava, "Hercoglossa kutchensisa new species from the Middle Eocene rocks of Kutch, India," Journal of the Palaeontological Society of India, vol. 23-24, pp. 55-57, 1980.

[21] R. P. Kachhara, K. Bigyapati Devi, and R. L. Jodhawat, "Molluscan assemblage from the marine Palaeocene sequence in southwestern Kachchh, Gujarat," Journal of the Geological Society of India, vol. 78, no. 1, pp. 81-91, 2011.

[22] R. P. Kachhara, R. L. Jodhawat, and K. Bigyapati Devi, "Molluscan biostratigraphy of the palaeogene sediments around Lakhpat, Kachchh, Gujarat, India," Journal of the Palaeontological Society of India, vol. 56, no. 1, pp. 17-28, 2011.

[23] K. Halder, "Cenozoic fossil nautiloids (Cephalopoda) from Kutch, western India," Palaeoworld, vol. 21, no. 2, pp. 116-130, 2012.

[24] K. Halder and S. Bano, "Cenozoic Corbulidae (Bivalvia, Mollusca) from the Indian subcontinent-palaeobiogeography and revision of three species from Kutch, India," Arabian Journal of Geosciences, 2014.

[25] V. d'Archiac and J. Haime, Description des animaux fossiles du Groupe Nummulitique de l'Inde, Seconde Livraison: Mollusques, Gide et J. Baudry, Paris, France, 1854.

[26] M. Cossmann and G. Pissarro, "The Mollusca of the Ranikot series. Part 1. Cephalopoda and Gastropoda," Memoirs of the Geological Survey of India: Palaeontologia Indica, New Series, vol. 3, no. 1, pp. 1-83, 1909.

[27] M. Cossmann and G. Pissarro, "The mollusca of the ranikot series. Part 2. Brachiopoda and lamellibranchia," Memoirs of the Geological Survey of India: Palaeontologia Indica, New Series, vol. 10, no. 2, pp. 1-31, 1927.

[28] L. R. Cox, "The fossil fauna of the Samana Range and some neighbouring areas: part VIII. The Mollusca of the Hangu Shales," Memoirs of the Geological Survey of India: Palaeontologia Indica, New Series, vol. 15, pp. 129-222, 1930. 
[29] L. R. Cox, "A contribution to the molluscan fauna of the Laki and basal Kirthar Groups of the Indian Eocene," Transactions of the Royal Society of Edinburgh, vol. 57, no. 1, pp. 25-92, 1931.

[30] F. E. Eames, "A contribution to the study of the Eocene in western Pakistan and western India. B. The description of the Lamellibranchia from standard sections in the Rakhi Nala and Zinda Pir areas of the western Punjab and in the Kohat District," Philosophical Transactions of the Royal Society of London B: Biological Sciences, vol. 235, no. 627, pp. 311-482, 1951.

[31] F. E. Eames, "A contribution to the study of the Eocene in western Pakistan and western India. C. The description of the Scaphopoda and Gastropoda from standard sections in the Rakhi Nala and Zinda Pir areas of the western Punjab and in the Kohat District," Philosophical Transactions of the Royal Society of London B: Biological Sciences, vol. 236, no. 631, pp. 1-168, 1952.

[32] M. W. A. Iqbal, "Mega-fauna from the Ghazij Formation (Lower Eocene) Quetta Shahrig area, West Pakistan," Palaeontologia Pakistanica, vol. 5, pp. 1-41, 1969.

[33] M. W. A. Iqbal, “The Tertiary pelecypod and gastropod fauna from Drug, Zindapir, Vidor (district D. G. Khan), Jhalar and Chharat (district Campbellpore ), West Pakistan," Palaeontologia Pakistanica, vol. 6, pp. 1-95, 1969.

[34] M. W. A. Iqbal, "Palaeocene bivalve and gastropod fauna from Jherruk-Lakhra-Bara Nai (Sind), Salt Range (Punjab) and Samana Range (N. W. F. P.), Pakistan," Palaeontologia Pakistanica, vol. 9, pp. 1-105, 1972.

[35] M. W. A. Iqbal, Oligo.-Miocene Bivalves \& Gastropods from Kirthar Province, Lower Indus Basin, Pakistan, vol. 51 of Records of the Geological Survey of Pakistan, Geological Survey of Pakistan, 1980.

[36] S. K. Biswas, "Tertiary stratigraphy of Kutch," Journal of the Palaeontological Society of India, vol. 37, pp. 1-29, 1992.

[37] K. K. Tandon, "On the discovery of mammalian and reptilian remains from the Middle Eocene rocks of S. W. Kutch, India," Current Science, vol. 40, pp. 436-437, 1971.

[38] E. Vredenburg, "A supplement to the Mollusca of the Ranikot Series," Memoirs of the Geological Survey of India: Palaeontologia Indica, New Series, vol. 10, no. 4, pp. 1-75, 1928.

[39] M. Cossmann, "Mollusques Éocéniques de la Loire-Inférieure. (Tome 2, Premier fascicule)," Bulletin de la Société des Sciences Naturelles de l'Ouest de la France 1, vol. 9, no. 4, pp. 307-360, 1899.

[40] F. E. Eames, "Notes on some Caenozoic molluscan species from the Far East," Molluscan Studies, vol. 28, pp. 145-155, 1950.

[41] A. K. Dey, "The Miocene Mollusca from Quilon, Kerala (India)," Memoirs of the Geological Survey of India: Palaeontologia Indica, New Series, vol. 36, pp. 1-119, 1961.

[42] R. Bieler, "Sanitation with sponge and plunger: Western Atlantic slit-wormsnails (Mollusca: Caenogastropoda: Siliquariidae)," Zoological Journal of the Linnean Society, vol. 140, no. 3, pp. 307333, 2004.

[43] B. Wade, The Fauna of the Ripley Formation on Croon Creek, Tennessee, United States Geological Survey Professional, Paper 137, 1926.

[44] N. F. Sohl, "Archaeogastropoda, Mesogastropoda and stratigraphy of the Ripley Owl Creek, and Parairie Bluff Formation," United States Geological Survey Professional Paper 331A, 1960.

[45] M. W. A. Iqbal, Bibliography of Tertiary Pelecypod and Gastropod Species of West Pakistan, vol. 18 of Records of the Geological Survey of Pakistan, Geological Survey of Pakistan, 1969.
[46] D. Merle, J. M. Pacaud, G. Métais et al., "Volutidae (Mollusca: Gastropoda ) of the Lakhra Formation (earliest Eocene, Sindh, Pakistan): systematics, biostratigraphy and paleobiogeography," Zootaxa, vol. 3826, no. 1, pp. 101-138, 2014.

[47] V. D. Borkar, K. G. Kulkarni, and S. Bhattacharjee-Kapoor, "Molluscan fauna from the Miocene sediments of Kachchh, Gujarat, India-part 4, Indarca, a new anadaroid genus," Journal of the Geological Society of India, vol. 83, pp. 290-294, 2014.

[48] L. R. Cox, "Fossil Mollusca from southern Persia (Iran) and Bahrein Island," Memoirs of the Geological Survey of India: Palaeontologia Indica, New Series, vol. 22, no. 2, pp. 1-69, 1936.

[49] S. L. Chattoraj, S. Banerjee, and P. K. Saraswati, "Glauconites from the Late Palaeocene-Early Eocene Naredi Formation, western Kutch and their genetic implications," Journal of the Geological Society of India, vol. 73, no. 4, pp. 567-574, 2009.

[50] R. Garg, V. Prasad, B. Thakur, I. B. Singh, and K. Ateequzzaman, "Dinoflagellate cysts from the Naredi Formation, southwestern Kutch, India: implication on age and palaeoenvironment," Journal of the Palaeontological Society of India, vol. 56, no. 2, pp. 201-218, 2011.

[51] S. K. Mukhopadhyay and S. Shome, "Depositional environment and basin development during Early Palaeogene lignite deposition, western Kutch, Gujarat," Journal of the Geological Society of India, vol. 47, no. 5, pp. 579-592, 1996.

[52] S. K. Mukhopadhyay and S. Shome, "Lithostatigraphy of preFulra supratrappean (Early Tertiary) sequence of NW Kutch: a reappraisal," Geological Survey of India Special Publication, no. 20, pp. 39-48, 1996. 

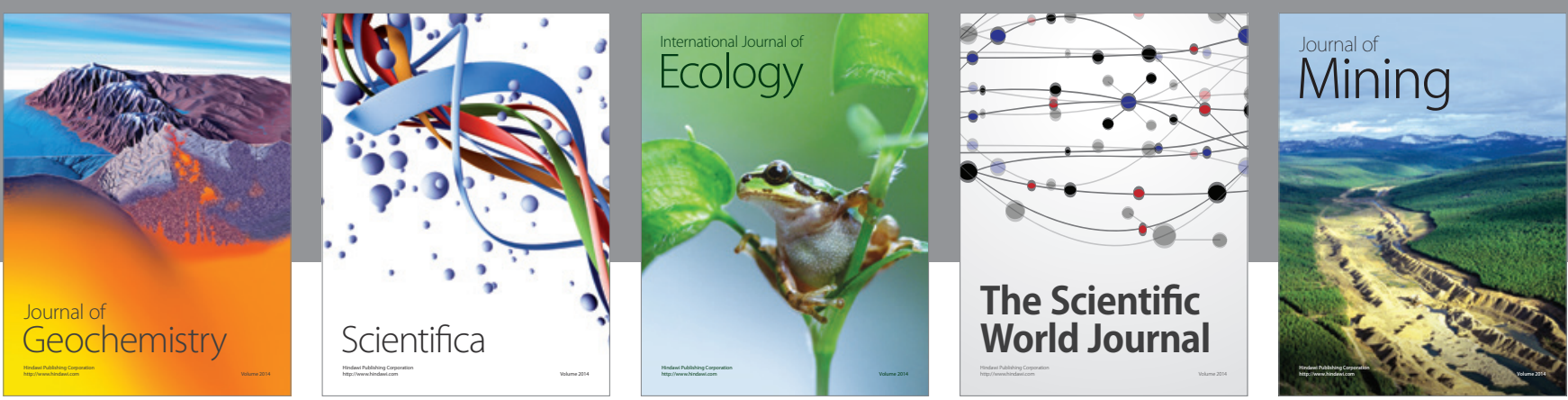

The Scientific World Journal
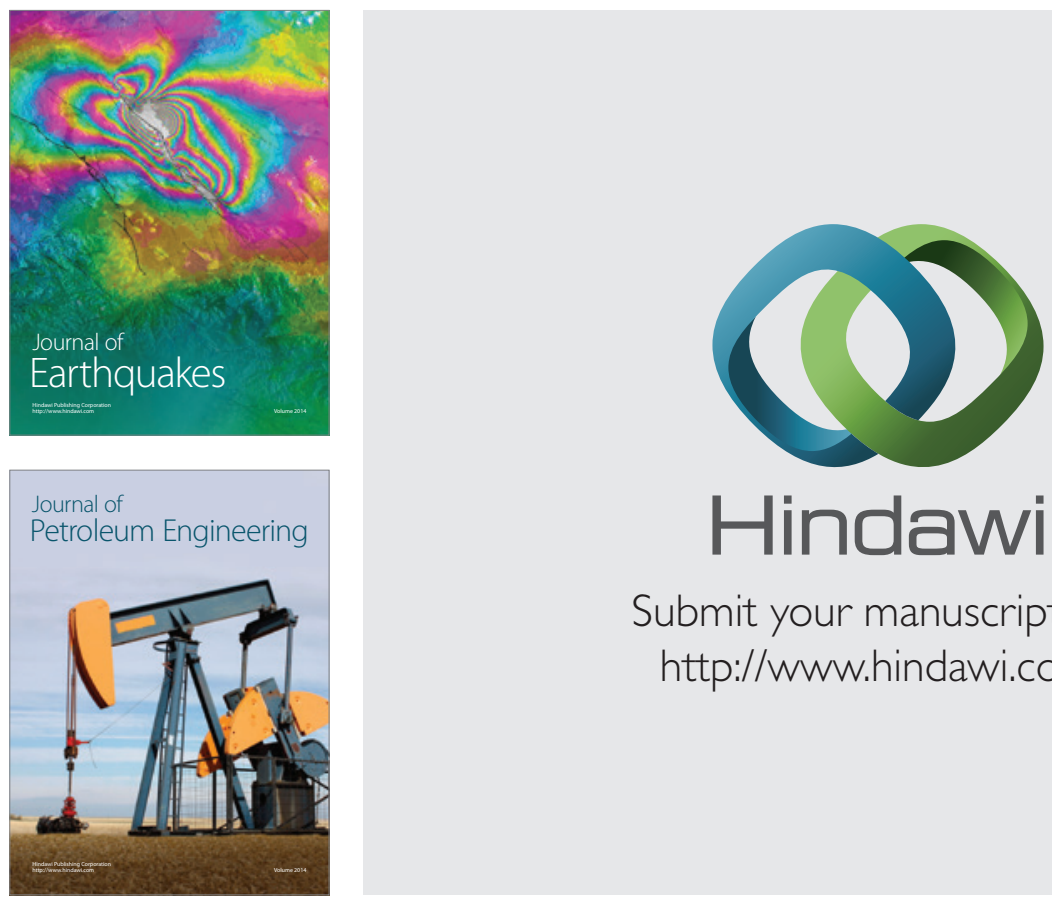

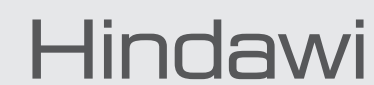

Submit your manuscripts at

http://www.hindawi.com
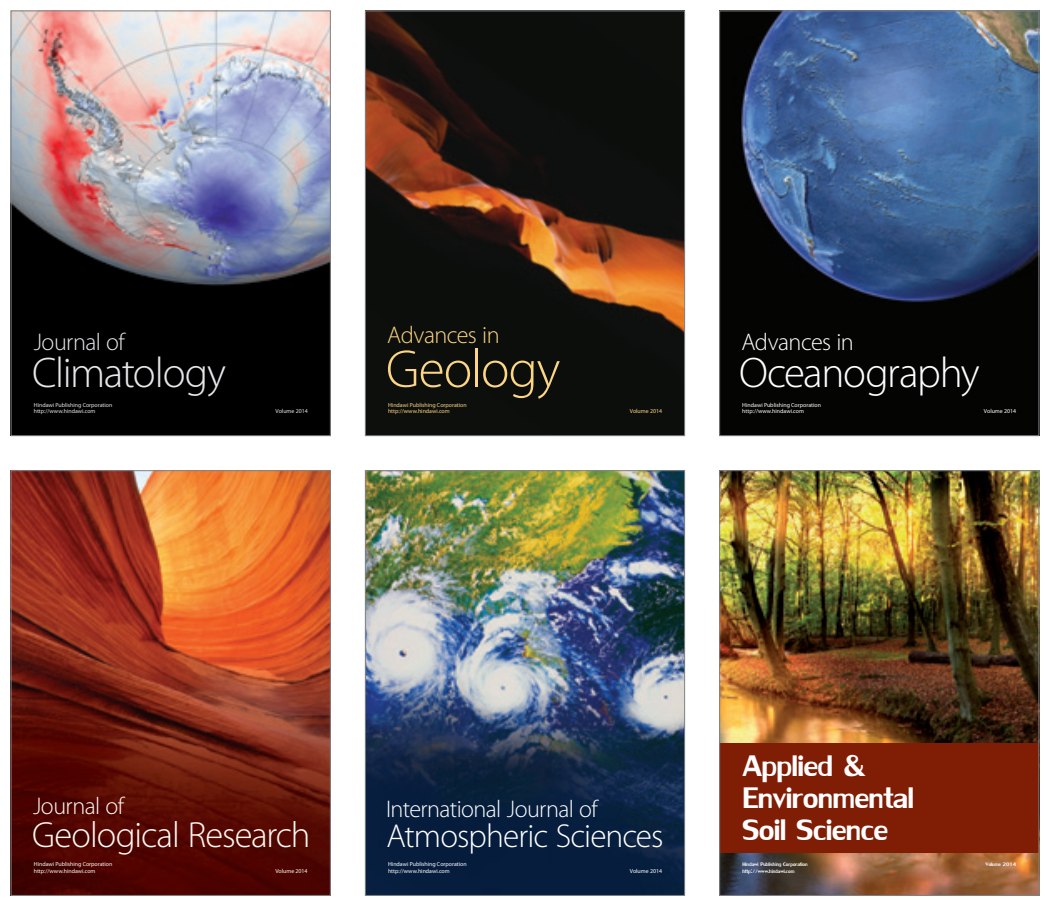
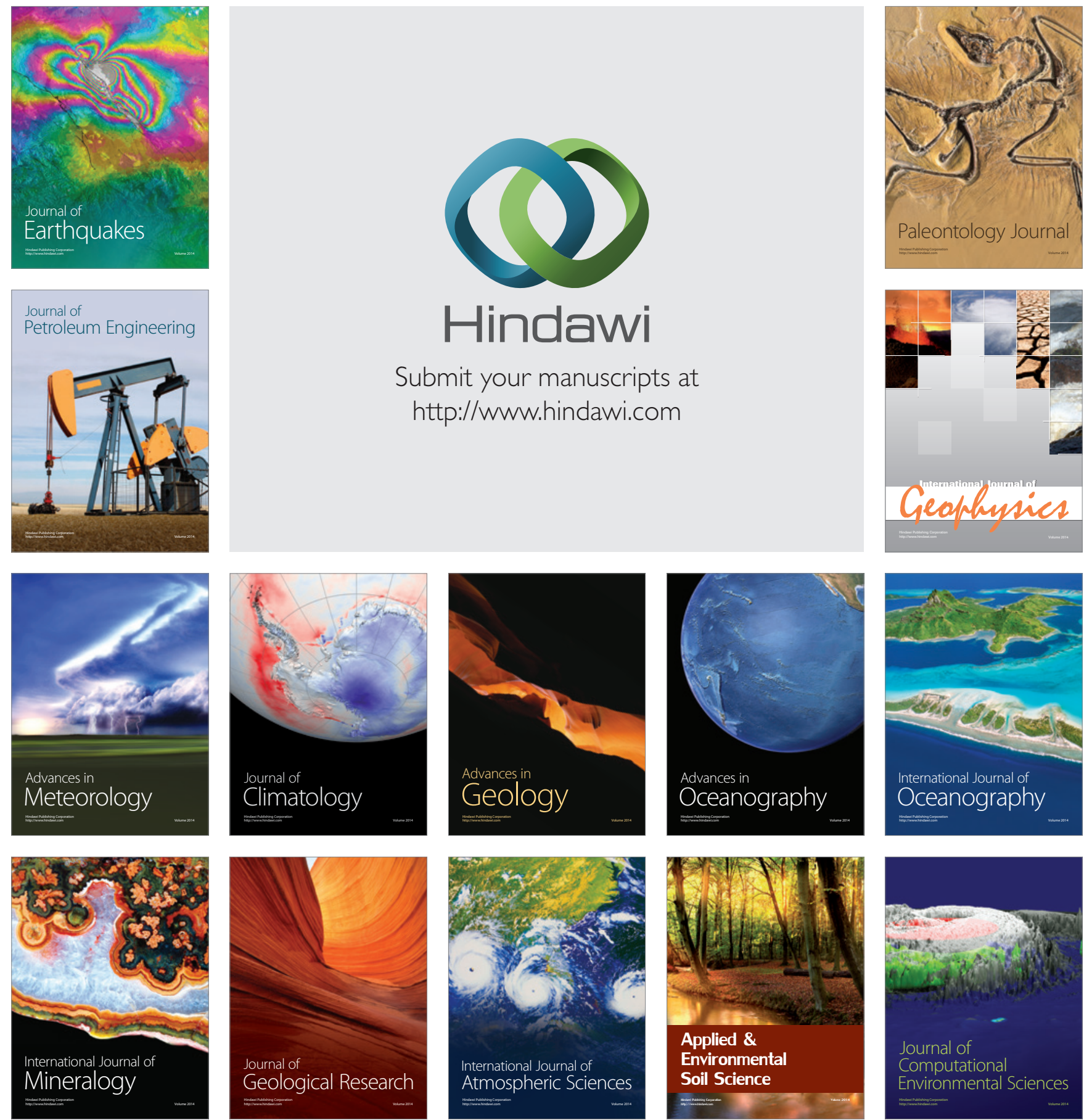